\title{
Gall crab city: an aggregation of endosymbiotic crabs inhabiting a colossal colony of Pavona clavus
}

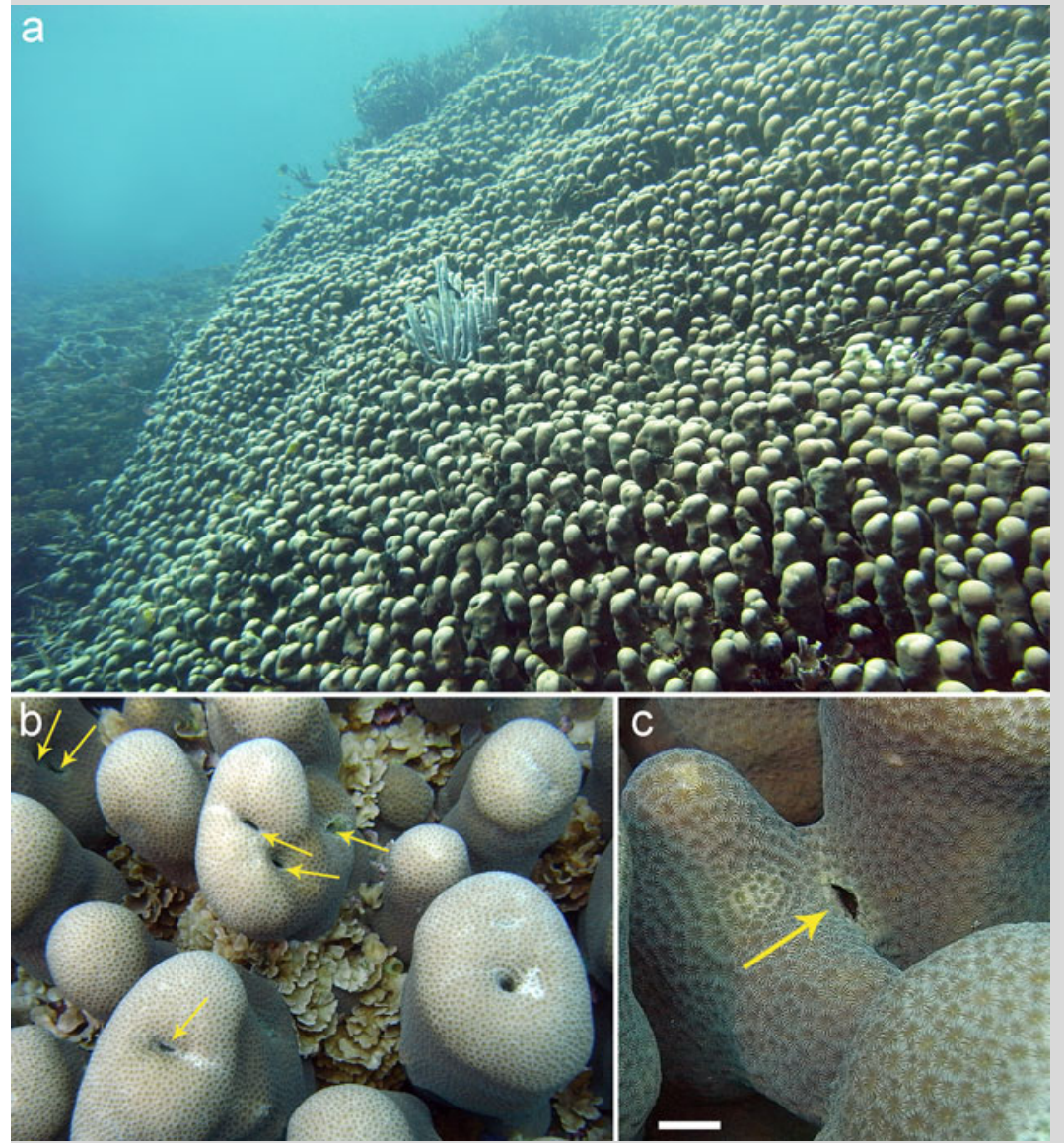

Fig. 1 Colony of Pavona clavus on a reef slope of Putus Island, North Sulawesi. a Part of colony with $100 \%$ cover. b Leptoseris papyracea corals in between columns (arrows crab pits). c Position (arrow) of crab pit (scale bar $1 \mathrm{~cm}$ )
Colonies of the scleractinian corals Pavona clavus (Dana, 1846) and Pavona duerdeni Vaughan, 1907, may form massive monospecific stands that extend over several meters across with thick columnar, club-shaped or laminar protuberances projecting from their upper surface (Veron 2000).

During a biodiversity survey on February 18, 2012, at Putus Island in Lembeh Strait (N Sulawesi, Indonesia; $1^{\circ} 31^{\prime} 21^{\prime \prime} \mathrm{N}, 125^{\circ} 16^{\prime} 37^{\prime \prime} \mathrm{E}$ ), a colony of $P$. clavus was observed encompassing a large area of the reef flat and slope (Fig. 1a). This area was approximately $50 \mathrm{~m}$ wide and covered the reef flat at $4 \mathrm{~m}$ depth from where it stretched downwards to $24 \mathrm{~m}$ depth on the lower reef slope, over a surface area of at least $1,250 \mathrm{~m}^{2}$. Some crevices in between the coral's columnar protuberances were partly filled by foliaceous Leptoseris papyracea (Dana, 1846) (Fig. 1b) and Pavona cactus (Forskål, 1775) corals. The columns themselves were inhabited by endofauna consisting of, among others, gall crabs of the genus Opecarcinus (Kropp \& Manning, 1987) (Brachyura: Cryptochiridae; see Kropp 1989) in a density of about $200 \mathrm{~m}^{-2}$. This density was estimated by counting the density of the protuberances and the number of crabs per protuberance (Fig. 1b, c). Little detailed information is known about the ecology and host specificity of gall crab species (Kropp 1989; Carricart-Ganivet et al. 2004), which may be related to their cryptic lifestyle. Besides residing in coral, they also feed on the host's mucus (Kropp 1986). The present observation shows that the often overlooked gall crabs may form large aggregations in Pavona-dominated coral reef communities.

Acknowledgments Field work took place during a Marine Biodiversity Workshop based at the Bitung Field Station, Research Center for Oceanography, Indonesian Institute of Science. Comments by three anonymous reviewers helped us to improve the manuscript.

\section{References}

Carricart-Ganivet JP, Carrera-Parra LF, Quan-Young LI, García-Madrigal MS (2004) Ecological note on Troglocarcinus corallicola (Brachyura: Cryptochiridae) living in symbiosis with Manicina areolata (Cnidaria: Scleractinia) in the Mexican Caribbean. Coral Reefs 23:215-217

Kropp RK (1986) Feeding biology and mouthpart morphology of three species of coral gall crabs (Decapoda: Cryptochiridae). J Crustac Biol 6:377-384 Kropp RK (1989) A revision of the Pacific species of gall crabs, genus Opecarcinus (Crustacea: Cryptochiridae). Bull Mar Sci 45:98-129 Veron JEN (2000) Corals of the world. Volume 2. Australian Institute of Marine Science, Townsville, p 429

B. W. Hoeksema $(\bowtie)$. S. E. T. van der Meij

Department of Marine Zoology, Naturalis Biodiversity Center, P.O. Box 9517, 2300 RA Leiden, The Netherlands e-mail: bert.hoeksema@naturalis.nl 